\title{
JACK JUNK
}

\section{Olaf Hartelie}

To cite this article: Olaf Hartelie (1919) JACK JUNK, The Mariner's Mirror, 5:6, 179-183, DOI: 10.1080/00253359.1919.10654880

To link to this article: http://dx.doi.org/10.1080/00253359.1919.10654880

曲 Published online: 22 Mar 2013.

Submit your article to this journal $₫$

山 Article views: 10

Q View related articles ¿ 
and the other to Davis Straits. At the bottom is a summary of the number of ships from the Greenland and Davis Straits Fisheries, from the year I772 to I82I. Those referred to as "clean" came home without any cargo. It will be noticed that a large number were either "lost" or " captured." As a record of the ships formerly in the whaling trade, and of the quantity of material they brought to Hull, the above is an interesting document.

For many of the facts relating to the movements, etc., of the early Hull whalers, I am indebted to the encyclopædic knowledge of an old friend, Mr. John Suddely.

\section{JACK JUNK.}

By Olaf Hartelie.

IT has always been a pet notion of mine that among the functions of our Society should be the rediscovery of rare books, prints, broadsides, and the like, the subject of which is concerned with matters connected with the sea. There must be many such items in existence, and it could not fail to be helpful to the objects of the Society if its members were to aid in the search for them, and, when found, to contribute information about them to THE MARINER's MirRor. Such a course, I suggest, would possibly result in the provision of replies to some of the problems which appear in our Notes and Queries ; would supply further interest- 
ing questions for solution; and would most certainly throw light on many matters naval or nautical.

It is particularly by illustrated books that I am attracted, because from this source much valuable information is obtainable in connection with the social habits, the manners and customs, and the dress of the seamen in the past. A good example of the kind of publication I refer to has the following title :-

\author{
JACK JUNK \\ or a \\ Cruize on Shore; \\ A \\ Humorous Poem \\ by the Author \\ of the \\ Sailor Boy.
}

London : Printed for Longman, Hurst, Rees, Orme, and Brown, and Sherwood, Heely, and Jones,

Paternoster Row.

I8I3.

The circumstances in which this little book came into my temporary possession are as follows :-It was thus described in one of the second-hand book catalogues of Mr. Thomas Thorp, of Chapel Street, Guildford : " Rare Portsmouth Item, printed at Gosport, and dealing throughout with exciting incidents in Portsmouth and the neighbourhood. Coloured plates. I8I3. The only known copy." Although I at once telephoned for it, I found that it had already been sold. However, Mr. Thorp kindly put me into communication with the purchaser, whom I discovered to be a member of our society, Mr. Lionel Foster. On hearing of my plan to publish details of this most interesting work in The Mariner's Mirror, Mr. Foster kindly placed it at my disposal for the purpose.

The poem by itself is not only interesting for its description of the cruise of a sailor ashore at the period with which it deals, but also by reason of the identity of its author. It was W. $\mathrm{H}$. Ireland, who became notorious for his wholesale manufacture of Shakesperian manuscript and autographs, who wrote "The Sailor Boy," and is therefore acknowledged to be the perpetrator of " Jack Junk." Ireland published a "Confession" of his misdeeds, but I have failed to find the connection which 
led him to write the poems concerning the British bluejacket; "The Sailor Boy," which was dedicated to Admiral Sir Edward Pellew, afterwards Lord Exmouth ; and "The Fisher Boy "all three uniform volumes and in many respects similar as regards their contents and arrangement. "The Sailor Boy" went through several editions and is by no means a scarce book. " The Fisher Boy " is also frequently to be met with in catalogues of second-hand books. Both volumes are illustrated, but not in colours, as is "Jack Junk," and why the last-named, so much the most interesting of the three, should have all but disappeared is not clear. Of course, as is not uncommon, in the circumstances, now that attention has been called to it other copies may be unearthed; and I may remark that, curiously enough, among my collection of nautical prints, is a set of the illustrations to the work, althongh I had no idea, until I saw the book itself, where they had come from. Moreover, while two of the illustrations in the book, the frontispiece and coloured title-page, are missing from my set, I have one which is not in Mr. Foster's copy, where presumably it should appear opposite page 76 .

Briefly, the story unfolded in the poem is this. Jack Junk, the British tar,
A hero who in gallant fray
Was never known to run away ;
But scars of honour nobly earn,
Upon the stem, instead of stern ;

is serving on board the Fame, riding at Spithead after a fiveyear commission on the East Indies Station. The Commissioner arrives aboard to pay the wages of the tars " in flimsies," and Jack fingers a hundred pounds and more, with which he intends to have a spell on shore.

Kick up the breeze with wenches neat, Enjoy the grog-dispense the treat ; And prove, at Portsmouth Point, a sailor Is always found true pleasure's nailer.

He gets permission as a liberty man, and arriving at Point, bears up for Capstan Square, a locality which many of my naval readers will recognise as being at the bottom of High Street. Jack's arrival is the subject of an illustration, one of those here 

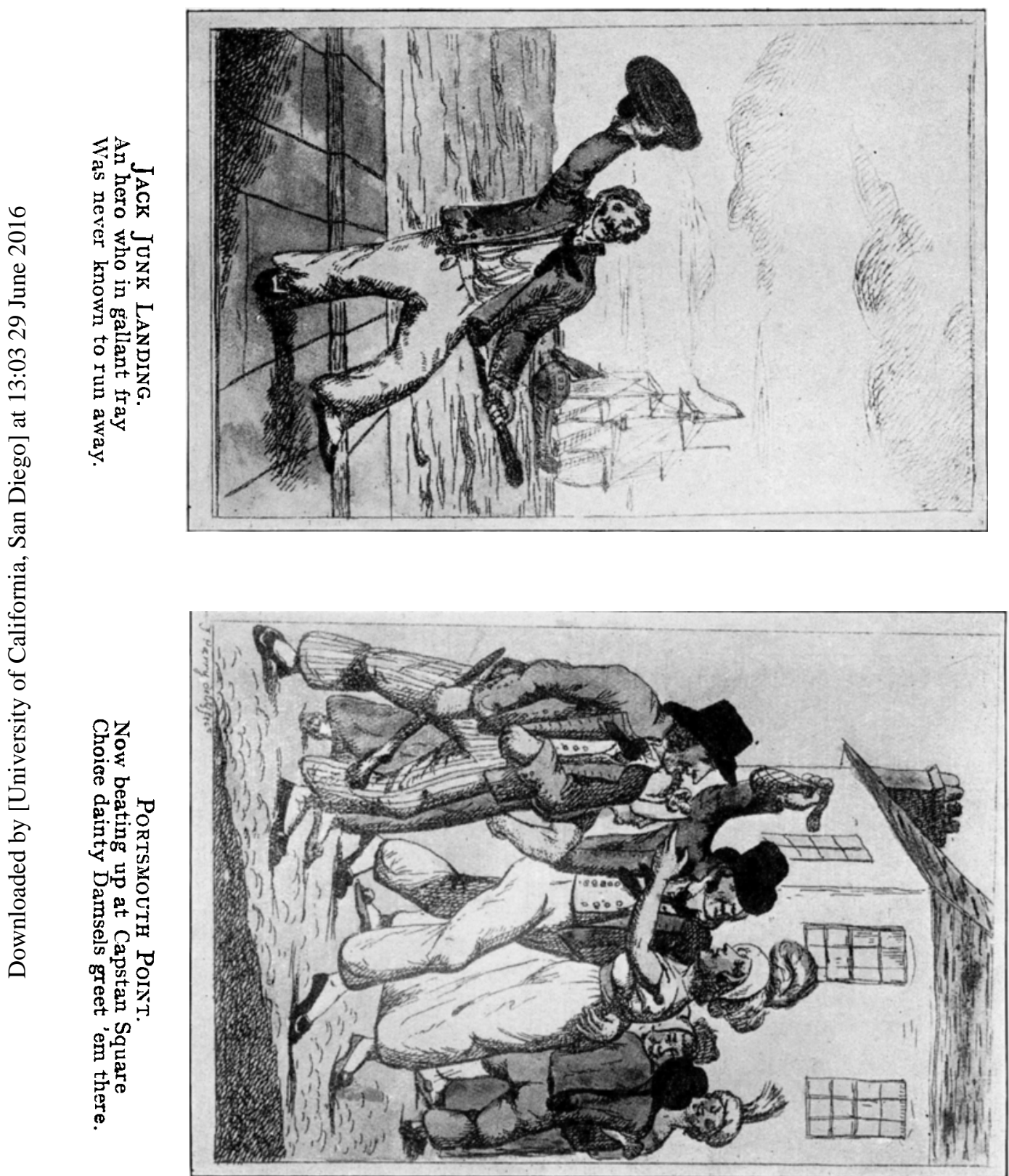


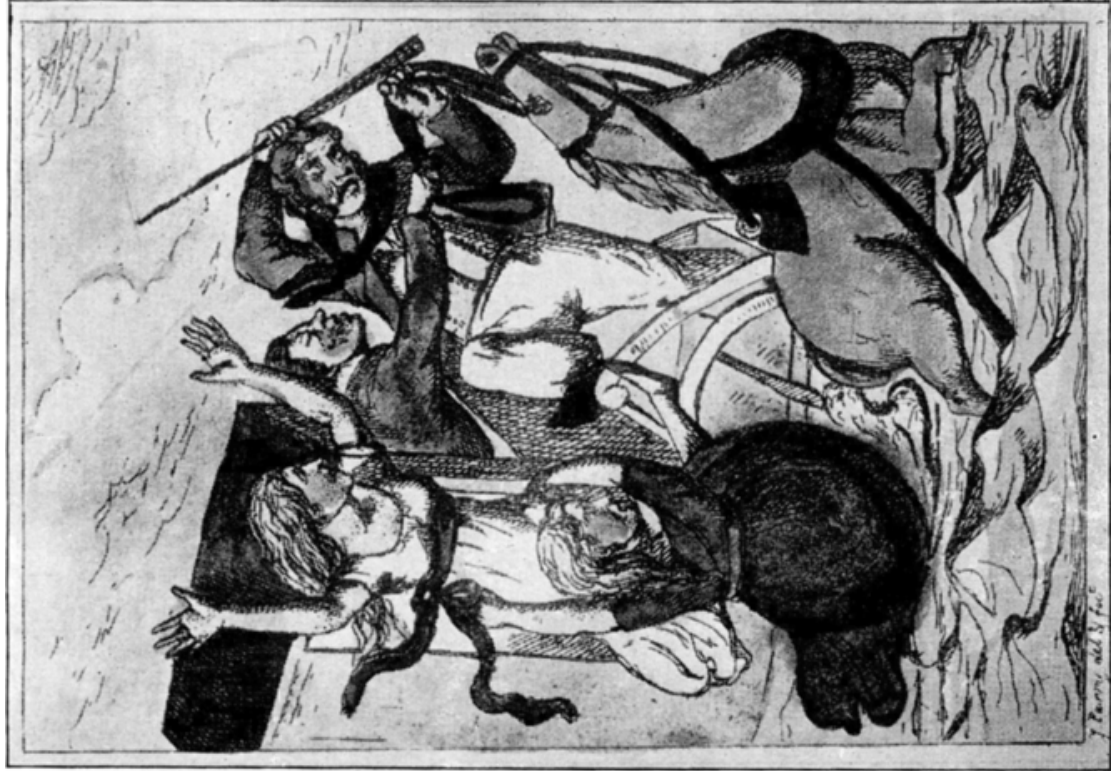

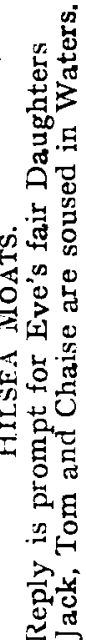

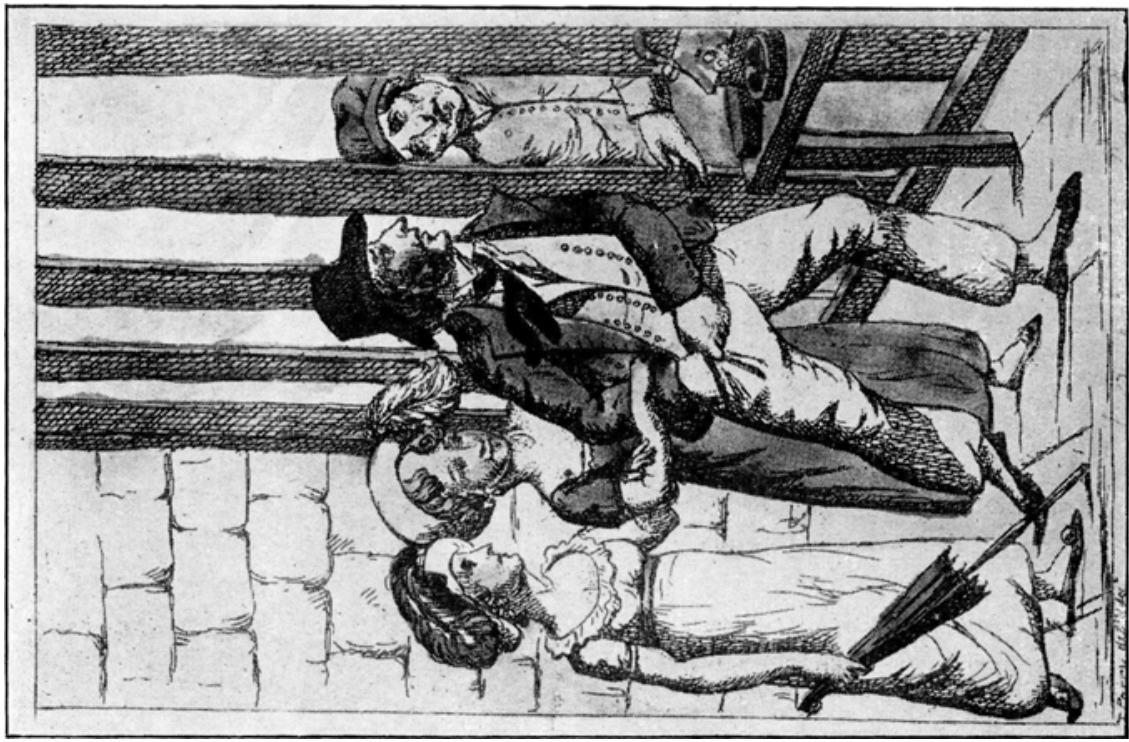

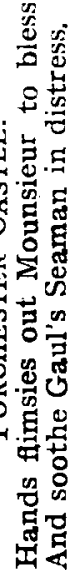


reproduced. With some of his companions, he makes the acquaintance of the ladies, and, having selected Mol Chauntress as his chère amie, they proceed to "The Jolly Sailor," for a carouse. This is the first of a number of houses of refreshment visited in the course of the cruise, the intimate details of which, including the names of the landlords, clearly indicate Ireland's familiarity with them. The choice of the name of Jack's girl was probably selected by the author on account of her talent as a vocalist, which is referred to in the poem, and here we get a suggestion of the origin of the term " chanty" as applied to songs favoured by sailors.

The second canto of the poem describes how Jack replenishes the wardrobe of his friend.

For Jack's above your common craft, So rigs his Mol right fore and aft, Her garb displaying to the view All colours of the rainbow's hue.

Then they take a "chaise and pair" for a drive, the progress of which is interrupted by calls at a number of wayside inns, many of which may be in existence to-day. At the Half-way Houses, they pull up at the Blacksmith's Arms, where Junk demands some " O be joyful," which is pronounced to be "stiff and good." Then at Kingston, they halt at "The Anchor Blue " for rum and milk, and again at Cosham at "The George" for gin and bitters. From this point, Junk,

Heedless of danger and his neck, Jumps on the roof and claims his deck.

Then in dashing style they bowl along until our tar " at Porchester arrives and to The Crown in glory drives." Here, having "wet their whistles" with the landlord Russell, they go to the castle, then used for the accommodation of French prisoners taken in the war. Jack's tender heart is touched by the piteous appeals of the captives, and he,

Hands flimsies out Mounseer to bless, And soothe Gaul's seamen in distress.

This incident is the subject of another illustration. The party now make ready for a return to Portsmouth, but not before 
taking some more grog aboard, and the post-boy, being a weaker vessel, gets so drunk that Jack has to steer the ship. As a result, the chaise is capsized in the Hilsea Moats, and the picture of this disaster is reproduced herewith. No great harm is done, but in order to keep out the cold they stop at "The Minden," manifestly so-called after the battle. More "prog" and "grog," and then, White Hart Row is reached in Portsea, where, after a change of clothes in Mol's lodgings, they adjourn to "The Lord Howe," in Rosemary Lane. Here they meet more boon companions, and, sallying forth, have a row with the dockyard maties, in which the sailors prove victorious.

Other episodes in Jack's career include an encounter with the constables in which the tars are overpowered and conveyed to the guardhouse, but, reinforcements arriving, Jack and his messmates escape. This is the incident of which I possess an illustration, and the verse runs :-

The row ensues, a direful tussle, Hell seems to lord it o'er the bustle ; 'Til tars, with leader Jack, make broom These lords of night and clear the room.

Meantime, the money has run short, and the tar pays a visit to a prize agent; a Jew, from whom he hopes to get an advance. $\mathrm{He}$ is unsuccessful, but gives the Jew a drubbing, until, help for the agent arriving in the shape of the town guard, Junk is once more incarcerated for the night, there to forget past scenes in renovating sleep.

The concluding canto describes how Jack returns on board the Fame, having been fetched off by Marines, and then we get another sidelight on naval conditions of the day in the fact that not only does Mol Chauntress, with her friends, visit the ship by permission, but from underneath her apron produces a bladder of gin with which to make merry. For no less than three weeks after this, the women remain on board, until the ship is ordered to sea again.

That Ireland's picture of Jack's spree was typical of the kind of thing which prevailed at the period is unquestionable, and finds corroboration in many other stories of the time. Nor is there any exaggeration in his description of the orgies which went on in the ships of war when in port. Unfortunately there is some evidence also that these scenes of brawling drunkenness and squalid debauchery were, if not encouraged, at least 
connived at by the authorities. The only excuse made for Jack's recklessness and extravagant ways was the contrast presented between his short-lived joys in harbour and the miseries of his existence at sea. Thus we find the hero of the poem spending five years' savings in about as many days, and then off to sea again.

The illustrations to the little book show the lack of uniformity in the dress of the seamen. Ireland, in his earlier book, "The Sailor Boy," dresses his young tar in a blue flannel jacket, white trousers, check shirt, shoes and hose, and in the illustrations to " Jack Junk," that personage is dressed in similar fashion, except that he is also given a yellow waistcoat, and a japanned hat. The shape of this hat is rather peculiar. The other seamen in the picture are variously attired in brown jackets, striped trousers, red or white waistcoats and black neckerchiefs. One of the men wears a pigtail. It is noteworthy that the only reference to the dress of the sailors in the poem is a suggestion that they wore neither belts nor braces :-

O'er hips he lugs his trowsers up.

Apart trom the fact that Ireland appears to have studied naval customs somewhat closely, the book's being printed and prepared at Gosport, gives a kind of authority to the illustrations. Its date is, from internal evidence, just before the war closed and a long spell of peace had brought about a very radical change in the dress of the Navy. 